\title{
Historein
}

Vol $2(2000)$

Heterodoxies: Constructions of Identities and Otherness in Medieval and Early Modern Europe

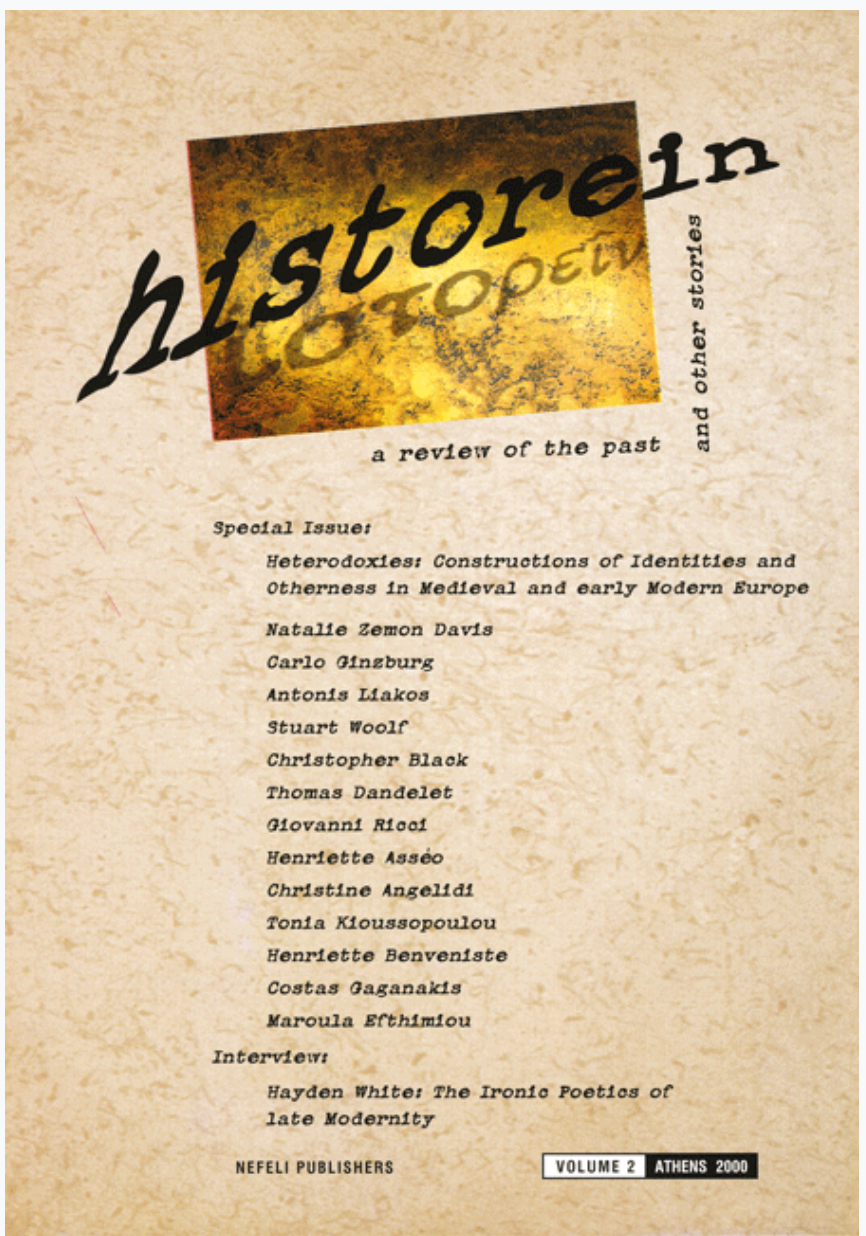

\section{Cannibalism and Knowledge}

Natalie Zemon Davis

doi: $\underline{10.12681 / \text { historein.109 }}$

\section{Copyright $\odot$ 2012, Natalie Zemon Davis}

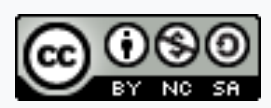

This work is licensed under a Creative Commons Attribution-NonCommercialShareAlike 4.0.

\section{To cite this article:}

Zemon Davis, N. (2012). Cannibalism and Knowledge. Historein, 2, 13-30. https://doi.org/10.12681/historein.109 


\section{Cannibalism}

\section{and}

\author{
knowledge
}

\section{Natalie Zemon Davis}

1. "Cannibal" in early modern times immediately evokes the image of those "New World" persons about whom Europeans coined the word: the Caribs and Arawaks of the Caribbean, the Mexica, the Tupinambas of the Amazon, and later the Iroquoians and Algonquians of the northeastern American woodlands. The sixteenth-century woodcuts of beautifully formed naked "savages" cutting up and burning corpses in a tropical clime come to mind. Sometimes the American anthropophagus is a hideous old woman, with breasts hanging to her waist.

But concern and accusations about the eating of human flesh and blood were widespread in Europe itself, and went back for centuries in Christendom. Pagans and Christians accused each other of anthropophagy already in the second century. Around 200 Tertullian claimed pagans also participated in a kind of "chain cannibalism" when they ate animals from the arena in which Christian martyrs had been slain. Cannibalism, both as real event and as metaphor, played a role in early Christian debate about the resurrection of the body and the Eucharist. God had the power to reassemble all the bits and pieces of a person's flesh in the final days, even those eaten by worms, or beasts or people. As Augustine put it, one knew from "both ancient history and the unhappy experience of our own days" that some people,

famishing for want and pressed with hunger, use human flesh as food... But... all the flesh which hunger has consumed finds its way into the air by evaporation, whence... God Almighty can recall it. That flesh, therefore, shall be restored to the man in whom it first became human flesh. 
For Irenaeus, the eternal life of the flesh was guaranteed by the fact that humans are "nourished from the body and blood of the Lord," a kind of "transcendent cannibalism [in the phrase of Caroline Bynum] that does not consume or destroy." To Augustine, Christ seemed to be "calling from on high saying, "I am the food of full-grown men. Grow and you shall feed on me. But you shall not change me into your own substance, as you do with the food of your body. Instead you shall be changed into me.'”'

In the medieval period, the Church hurled the accusation of cannibalism against the proponents of dualistic heresies, such as the Cathars, along with other bodily transgressions. Other wicked people were thought to feed on human flesh by turning themselves into wolves for a time. Meanwhile the Jews were said to be killing Christian children to drink their blood or use it in Passover matzoth. Among themselves, the Jews spoke with derision of Christians who ate their god in ceremony. ${ }^{2}$

Religious controversy was not the only setting in which charges of cannibalism were made. The famines that beset Europe from the early thirteenth century through the sixteenth century regularly generated cases of babies or young children being eaten. Also by the early modern period, maritime law, at least in England, assumed that there might well be cannibalism in the wake of shipwrecks and allowed for a procedure in which victims would be selected in this distressing situation.

Thus, cannibalism was by no means a simple fact associated with New World people in the sixteenth and seventeenth centuries, even though Europeans wrote about it most fully and obsessively in connection with them. This literature has been assessed by scholars of our own post-colonial period primarily in terms of the construction of alterity - of an Other, by whom one's own identity is defined and confirmed - and of the legitimation of European conquest and Christianization. (Some twentieth-century commentators doubt that prisoners were ever slain and eaten by the Amerindians, but archaeological evidence from burial sites in northeastern Canada and the southwestern United States confirms such events.) The alterity interpretation fits well with Mary Douglas's explanation for food taboos: every society has its own conceptual structure that establishes purity and order, and what does not fit in with it, what is anomalous or disturbing becomes thereby polluting and dangerous. ${ }^{3}$

Clearly, the American cannibal plays in part the role of Other, and of an Other deserving of conquest. Yet even the few examples of European imaginings, metaphors, and actions given above suggest that alterity may not be the whole story. Quite apart from the ambivalence always associated with prohibition, there is a possibility that consumption of human flesh in some forms was not always viewed with revulsion and terror. More important, written reflection on cannibalism could lead not only to a dead-end - a constructed Other whose culture remains opaque to the self-righteous European - but also to insight into difference and the nature of one's own world. 
This essay will consider three early modern texts concerning cannibalism - two of them fictional, one drawn from a travel report - in terms of their movement toward knowledge: a chapter from François Rabelais' Pantagruel, Jean de Léry's Voyage to the Land of Brazil, and a story by the late seventeenth-century Jewish merchant woman Glikl bas Judah Leib. In the case of Jean de Léry, I am appreciative of the nuanced and rich treatment by Frank Lestringant in his 1994 book Le Cannibale, though I will take the argument in a somewhat different direction. ${ }^{4}$

Before turning to these accounts, let us recall that they were produced in societies that had extensive rules concerning the consumption of animal flesh. Though Christians might mock the Jewish prohibitions, claiming that the Jews did not eat pork because they were actually pigs themselves, certain of the commands of Leviticus 11 were reflected in the customary non-Jewish diet: herbivores, the cud-chewing animals of Leviticus, were what Christians preferred to consume, rather than carnivores or carrion-eaters. Ascetic practice kept meat off the tables in mendicant houses and convents, and of course, all Catholics were to hold to such denial during Lent and other fast days. Indeed, Christian teaching, still cited by seventeenth-century Protestants, proclaimed that meat-eating was a sign of the fallen state of humankind: until the expulsion from Eden (some said until the Flood) men and women had been herbivorous. ${ }^{5}$

Meanwhile, medical texts and popular beliefs sorted out certain foods for persons depending on their humor, age, and social status. "Drier" meat like veal was recommended for the young, "humid" meat like mutton for the old. No one should eat much meat at all during the threat of plague, and certainly not heavy red meats. In ordinary times, heavy greasy meats were needed by harvesters, gleaners, and other field hands, said Dr. de Monteux in 1559, such "warm" food conforming to the heat engendered by their exercise. ${ }^{6}$ "Homme de boeuf, homme de porc," went the popular saying ("a beef and pork man"):

by which is meant a gross, uncivil and ungenteel (malhonneste) man, badly taught, such as are ordinarily those from the lowest and most common level of the people. [And this is said] because the food most familiar to such persons is lard, pork, beef and other heavy meats. In contrast, more genteel (honnestes) and delicate persons, of more attractive life and customs, are nourished by more delicate foods like mutton, capons, partridges and other light meats.?

The assumption often underpinning these medical and popular views was that like goes with like, like nourishes like. Surely, this belief could not be extended to the analogous case of humans eating humans. The early Christian Athenagoras had maintained that human flesh bore no nourishment for humans and that cannibals would be thin and emaciated. But the Mexica and Tupinambas were full-bodied and, according to European report, liked the taste of their fellows. What made cannibalism so wrong-so "ferocious" and "inhuman"-in the eyes of the faraway Spanish theologian Francisco de Vitoria was its ignorance about where humans stood in the great 
chain of being. Humankind had been created by God just below the angels, and above the animals. Men and women could control the animal kingdom, but there was a limit to what they could do to each other. Human beings belonged ultimately to God, and "Man is clearly not a food for man." 8

The peoples of Mexico would have described their relation to nature in terms of exchange and cycles of transformation rather than hierarchy, but Vitoria believed that centuries of education under Spanish tutelage could get them to change their minds. ${ }^{9}$

2. In 1532, seven years before the Dominican Francisco de Vitoria penned his manuscript De Indis in Salamanca, the physician and ex-Franciscan François Rabelais published his Pantagrue/ in Lyon. It was the first appearance of his great ongoing novel about the princely giant Pantagruel and his father Gargantua. It also introduced Panurge, whom Pantagruel met during his student days at Paris and whom "he loved for all the rest of his life."

When Pantagruel first lays eyes on Panurge, the prince is struck by the contrast between Panurge's good looks, on the one hand, and his bruised and dishevelled appearance, on the other. He asks Panurge to tell him who he is, where he is coming from and what he seeks. Whereupon Panurge answers him in thirteen different languages, some current, some made-up, asking in various ways for food. Finally, he explains in French, his "natural and mother tongue," that he had been a prisoner among the Turks and that he will tell them about his escape at another time, but that he is in desperate need of something to eat. Whereupon the prince gives him food and a place to sleep. ${ }^{10}$

Sometime later, while Pantagruel and his company are cheerfully drinking wine together, Panurge is reminded of his days among "those devilish Turks." He considers them very unfortunate since the Koran forbids all Muslims even a drop of wine; for that prohibition alone, Panurge says, he would never put himself under their law.

He then tells the story of his escape, assuring Pantagruel that every word he will say is true. ${ }^{11} \mathrm{He}$ had been taken prisoner at Mytilene. As his listeners would know, that meant he had been part of the ill-fated French army that had fought the Turks at Lesbos in a Crusade inspired by the pope in 1502. The Turks, Panurge claims, were planning to roast and eat him. Larded and placed on the spit like a rabbit, Panurge prayed to God to deliver him from these "treacherous dogs" and then managed to get a firebrand in his teeth while his cook was dozing. Hurling it from his mouth, Panurge started a real fire. His captor rushed out and, perceiving his house and goods going up in smoke, called on all the devils and tried clumsily to commit suicide with Panurge's spit.

At this, Panurge offered with polite guile to kill him neat and clean; otherwise he would just wound himself badly and spend the rest of his life disabled and in barbers' hands. (Panurge was presumably speaking Turkish throughout the episode - another language known!) The Turk accepted, and gratefully gave Panurge six hundred Turkish coins, rubies, and diamonds as a 
reward. Panurge then tied his captor's hands and feet, slit his throat, put him on the spit over the fire, and departed ("I'm not lying in any word," Panurge again assures his listeners).

Meanwhile his captor's neighbors were running through the streets to put out the fire, but seeing Panurge "half-roasted, had natural pity for me, and threw all their water on me, refreshing me joyously... They offered me something to eat, but I ate little of it, for they gave me only water to drink as is their mode."

By now the fire had spread to some 2000 houses. He looked back from the city gate "like Lot's wife," but instead of being turned to a pillar of salt (Gen. 19: 26), he was filled with delight at the beautiful fire. Still God sent him a last test: 1,311 dogs - real Turkish dogs rather than metaphorical ones - attracted by the odor of his partly burnt flesh, rushed at him to eat him up. Remembering the morsels of lard still attached to his body, Panurge threw them to the dogs. While they were fighting over them, Panurge escaped in merriment, and concludes his tale, "Iong live the roasting spit!"

Panurge is a complex figure in Rabelais' novel. He has been compared to Mercury, god of eloquence, with many languages at his disposal and an answer to everything, god of merchants, crosser of boundaries, symbol of mediation. Sometimes Panurge has a good argument in his mouth, as in the case of his first meeting with Pantagruel: Panurge's listeners ought to have come to his aid promptly, for charity and community must stretch beyond differences in language. But scholars have also claimed that Panurge is the hero, the victimized hero, of the Turkish tale and that the story shows the limits of Rabelais' Christian humanism. The Turks are portrayed as dogs throughout, so the argument goes: Rabelais' sympathy stops with the borders of Christendom. ${ }^{12}$

This seems to me a mistaken reading. The Turks are described by Panurge as possible cannibals and as cruel - the cook did try to roast him - and surely as fools and bumblers. But some of them are shown as kind, full of "natural pity" for the burnt Panurge and offering him water and food. Panurge comes out the worst in the episode. He kills his captor in a vindictive way, which he describes with relish. He is ungracious about the food offered him by his captor's neighbors. Unlike the helpful Turks, he has no "natural pity" as he looks at the whole town on fire, but rather rejoices in the catastrophe. The money and jewelry he obtained by devious politeness he let slip out of his hands somehow "like the snows of yesteryear." His arrival in France penniless and starving turns out to be due as much to his own profligacy as to his imprisonment by the Turks.

Rabelais has created in this chapter a Panurge who is a braggart and a liar. His claims to veracity here ring false: earlier he had maintained that his experiences were "more marvelous than those of Ulysses," but everyone knew that Ulysses was a famous liar. Though Panurge could evidently speak enough Turkish to converse with his captor and his benefactors, he is oddly (or disingenuously) ignorant about the Turkish prohibition against pork. Roasting him with lard would have made him inedible by the same Koran that forbade the drinking of wine. Panurge's accusation of cannibalism is suspect within the bounds of Rabelais' story. 
In short, Rabelais' account does not create an Other of cannibalistic Muslim Turks. Rather through the blind spots, callousness, and lies of Panurge in regard to the Turks, Rabelais shows his readers the process by which alterity is imagined and reinforced.

3. In 1563, around the time that the first posthumous editions of Rabelais' Fifth Book were being published, a manuscript by a young Protestant pastor was confiscated at the city gates of Lyon. The author's name was Jean de Léry, and the manuscript recounted his ten months (from late February 1557 to early January 1558) with several other Protestant men in the land of Brazil. Léry managed to rewrite his book in the midst of a busy vocation spreading the Reformed Gospel in France, and in 1576 retrieved his initial version. Two years later appeared his Histoire d'un voyage fait en la terre du Bresil, autrement dit Amerique. ${ }^{13}$

Léry wanted both to perpetuate the memory of a trip made with the hope of establishing the Reformed worship of the Lord in America and to tell from "[his] own knowledge... from [his] own seeing and experience" about the "way of life... among the savages called the Tupinamba... and other singular and hitherto unknown things in their land." He wanted also to correct lies about their voyage: those disseminated by the nobleman who had initially sponsored the expedition and then had turned violently against it and the Reformed faith, and those disseminated by a Franciscan friar, André Thevet, who had spent only two and a half months in Brazil. But Léry also knew that some of the things he had to report were "so marvelous" that he himself might not be believed: things "so fantastic and prodigious... that experience itself can scarcely engrave them upon the understanding of those who have in fact seen them." He would do his best to tell the truth in a simple unadorned language and hoped his book would also redound to the glory of the Lord. ${ }^{14}$

The cannibalism of the Tupinambas - that is, their ceremonial consumption of the cooked flesh of prisoners captured in war - was one of the "monstrous and prodigious" facts of his narrative, but it was not used by Léry just to create alterity. The eating of human flesh was immensely "cruel," he said, and the first practice the Tupinambas would have to abandon if they converted to Christianity. But describing and reflecting upon it led Léry to some insights into the workings and perpetuation of cultural systems (as we might call them today), both in the New World and at home.

To begin with, the eating of human flesh was embedded in a whole story about the Tupinambas, from their bodily appearance, ornaments, and child rearing habits, to their beliefs and burial customs. He remembers the people vividly, old and young - "even now it seems to me that I have them before my eyes" - and a French odor like starch years later will call to his mind the scent of manioc flour being prepared. ${ }^{15}$ There was much that he appreciated about them, including their polite generosity and the sexual modesty of their young people. Some of their meats, such as the hare-like agouti, were delicious. The cruelty of their cannibalism did not automatically contaminate the rest of their activities. 
Secondly, the consumption of human flesh was not a disordered chaotic event, but one heavily ruled by traditional custom and ceremony. ${ }^{16}$ Prisoners were in part a source of labor: the women were set to work at gardening or gathering oysters, men at hunting and fishing. The men were also given wives from among the Tupinambas, who cohabited with them, though any infant born of such unions was killed and eaten. (As we might put it, there was no aspect of population replacement in the Brazilian system, in contrast to the Iroquoians and Algonquians in the northeastern American woodlands, where prisoners were incorporated either by cannibalism, or by permanent enslavement, or by full adoption or marriage into the community.)

Though the period of labor and of male marriage might stretch to years, the end was always known. A festival was held, the prisoner was dressed in feathered regalia, and he drank and danced for hours, boasting of his past feats and of how many Tupinambas he had once consumed. (Léry gives evidence of women sometimes being slain and consumed, but adds no details about their garb or speeches.)

The prisoner was then killed with a quick blow to the head and the body prepared for blanching and roasting, the iron knives introduced by the French making the task all the easier. The roasting was done on a Tupinamban grill called a boucan. (Léry interjects: "I here refute the error of those who, in their maps of the world, have represented and painted the Brazilian savages roasting human flesh on a spit, as we cook mutton legs and other meat... These things are no truer than the tales of Rabelais about Panurge escaping from the spit larded and half-cooked. ${ }^{17}$ At least one reader of Rabelais understood that he intended to catch Panurge in a lie!) The prisoner's wife, who had made at least a token lamentation over the slain man, was often the first to seek a morsel of his flesh.

Léry then interprets these events, which he has called "ceremonies." They do not eat human flesh for nourishment, even though they say the taste is good, but rather out of vengeance against their enemies, who have slain and eaten their kin: "their chief intention is that by pursuing the dead and gnawing them right down to the bone, they will strike fear and terror into the hearts of the living." ${ }^{18}$

Though his generalization stops with this, Léry also shows how the consumption of human flesh is valorized. A great warrior - a Querre-muhau, to use the phrase from Léry's glossary - is a man who has also eaten many enemies; his soul will dance in beautiful gardens with his ancestors after his death. He is esteemed by his children and wife, and his sons long to be like him when they grow up. Children are washed in the blood of the victim at the ceremony, and the executioner is scarified as an honorable sign of his action. Bravery and braggadocio are what is expected if one is a prisoner (they are part of the same system of values), and some Portuguese prisoners were mocked when they wept as their beards were pulled out: "Can it be," the Tupinambas asked before they killed them, "that you have so bravely defended yourselves, and now, when it is the 
moment to die with honor, you show that you have not even as much courage as women?"19

Finally, Léry relates two conversations with women that show how deeply accepted were the warrior ethic and eating-or-being-eaten as a form of incorporation. In one case, he had purchased from the Tupinamba a woman prisoner and her son and told her that he hoped to take the lad back to France with him. "She replied... that she had hoped that when her son grew up he would have been able to escape and go back and join the Margaia [the Tupinamba's enemies] so as to avenge them, but that she would have preferred that he be eaten by the Tupinamba than go off so far from her." In the other, he approached a woman prisoner about to be slain and urged her to pray to her god as he would teach her to do. She laughed and asked, "What will you give me if I do as you say?" Léry answered, "Since you believe the soul to be immortal, think what will become of it after your death." She laughed again, and was killed shortly afterward. ${ }^{20}$

In fact, the Tupinambas believed not only in the immortality of the soul, but, Léry said, in a version of the resurrection of the flesh. Though he did not speculate on this, they had evidently decided, like the Christians of the early Church, that being chopped, chewed and swallowed need not be an impediment to that final transformative event.

Cannibalism not only spurred Léry to social-cultural reflection on a distant people. It also led him right back to Europe and Europeans. The consumption of human flesh was not so prodigious and strange after all. Some of the Frenchmen from Normandy, interpreters who had lived among the Tupinambas for several years, had not only conducted themselves lewdly with the women but "surpassing the savages in inhumanity, even boasted in my hearing of having killed and eaten prisoners." In France itself, during the Saint Bartholomew's Day massacres and other religious riots, Catholics had eaten the hearts and livers of murdered Protestants, had sliced fat off Protestant corpses and sold it to the highest bidder, and more. At least, observed Léry, the Tupinambas attacked enemy peoples; in France, the targets were relatives, neighbors, and compatriots. (Oddly enough, Léry reports without indignation that his ship's surgeon took back to France not only many jars of a healing ointment used by the Tupinambas, but also "an equal quantity of human fat that he had collected when the savages were cooking and roasting their prisoners." ${ }^{21}$ )

There was also the cannibalism brought on by famine, which Augustine had written about long before. In the sixteenth century it could tempt Protestants as well as Catholics, as Léry had experienced himself. On the return trip from Brazil, beset by terrible storms, leaks, and navigational errors, the ship ran out of provisions with three or four weeks of sailing to land still ahead. Sailors died of starvation, their papist vows to Saint Nicolas bringing them no help, and were thrown overboard to the fish. Every possible item that could be turned into food was tried: the rats, the parrots and leather shields being brought home as souvenirs, morocco collars. Thirst was even worse, and they were reduced to drinking filthy water sucked from the tar 
caulking and from the deck.

Léry commented on the consequences of this weakened state and the madness that it engendered. "I can testify that during our famine on the sea we [he meant his fellow Protestants] were so despondent and irritable that although we were restrained by the fear of God, we could scarcely speak to each other without getting angry, and what was worse (God pardon us), without glancing at each other sideways, harboring evil thoughts." After land was finally sighted, the captain admitted that if one more day had past, "he had resolved for certain not to cast lots, as some have done in such distress, but, without saying a word, to kill one of us to serve as food for the others." 22

Fifteen years after this voyage, while a pastor in Sancerre, Léry lived through a famine again, this one brought on by a successful Catholic siege of the town. Here the fear of God did not restrain everyone, and a father and mother were discovered to have eaten their own child and some soldiers to have consumed the flesh of the dead. Léry told the story immediately in his 1574 Histoire mémorable de la ville de Sancerre, but more important for the argument here, he repeated the account of Christian cannibalism in his book on the "savage" Tupinambas. ${ }^{23}$

Of course, these are unusual cases, brought on by the ferocity of religious passion and the madness of hunger. But thinking about the consumption of human flesh he had seen in Brazil, Léry made a leap through metaphor to more quotidian and sanctioned activities in France. The usurers, who sucked the blood and marrow of the poor, were even crueler than the savages across the ocean. The Eucharist and the sacrifice of the mass especially were infused with cannibalistic feeling by the Catholic doctrine of transubstantiation. If one misread Scripture to think that consecrated bread and wine were really changed into the body and blood of Christ, then one really wanted to eat the Lord's flesh-and raw, added Léry, not even roasted. ${ }^{24}$

Léry is not the first to make this accusation; earlier Protestant tracts say as much. What gives it peculiar force here is context; that is, the comparison is made by a voyager who claims to have witnessed the ceremonial consumption of human flesh. The Catholic priest, too, is conducting a cruel and savage liturgy.

Léry's attack also betrays a distinctive Protestant or at least Calvinist concern about incorporative processes. In defending the Lord's Supper over the Catholic mass, pastor Pierre Viret scoffed at the priest taking communion all by himself in front of the whole body of worshippers - as though one person could eat for another person! But, of course, one person can sometimes eat for another person: the pregnant mother who eats for herself and for the child that feeds on her. Such an example is not relevant, Viret insisted: the Reformed believer stands always on his own, integral and autonomous before God. ${ }^{25}$ What was terrifying about cannibalism was, in one image, being chewed and swallowed or wanting to chew and swallow another, but in another image, it was the dependency of eating off another in the womb. 
4. Jean de Léry's Brazil book went through many editions, the last one in 1611, two years before he died of the plague. Perhaps Léry heard before his death of another French traveller to Brazil, one Jean Mocquet, keeper of the royal cabinet of curiosities for Henri IV and later for Louis XIII. Mocquet's voyage took him from the Amazon to the Caribbean over only three months in the spring of 1604, and his description had much less ethnographic richness than that of Léry. But when his account of it and other travels was finally published in 1616, it included one tale different from anything the Protestant pastor had reported. ${ }^{26}$

Mocquet had noticed the pilot of an English ship when their boats met near the island of Margarita off the coast of Venezuela. His own pilot told him how the Englishman had been shipwrecked several years before off the Spanish West Indies. Saved by a Carib woman, to whom he promised marriage, he wandered with her for two or three years, hoping one day to find an English ship. She provided him with food, served as his interpreter with Amerindians whom they met along the way, and had a child by him. Finally they came upon an English boat, but he boarded it alone, "ashamed to bring with him this naked Indian woman and to have had a liaison with her." Devastated and enraged by her abandonment, the Carib tore their child in half, threw one half toward the English boat, and went off with the other in mourning and sorrow. Questioned by the fishermen, the pilot answered that "she was just a savage and they should take no heed of her." Mocquet found the pilot's behavior wicked and ungrateful and regarded him with horror.

Jean de Léry had mentioned Norman interpreters who had gone native, living and having children with Tupinamba women and even killing and eating prisoners. But he had told no story of European abandonment, and the "savage" sorrow expressed by the women was occasioned by the departure of their own Brazilian sons. Nor do such motifs occur in earlier accounts of captured Europeans finally finding their way back to their compatriots. Cortés had offered to ransom two Spaniards shipwrecked and living for years among the Maya, but only the celibate ex-priest had accepted, the other one, Gonzalo Guerrero, saying "I am married and have three children and the Indians look on me as a... captain in wartime." Mocquet's English pilot may be the first formally-told example of love-and-abandonment between a European man and a "savage" wife, a tale in which the man's behavior arouses more horror than the woman's, a tale with a long future ahead of it. ${ }^{27}$

Mocquet's book itself had several editions including a German translation published in 1688, with an engraving of the Carib woman tearing her child apart. ${ }^{28}$ In this form, it was either read by or read aloud to an Ashkenazic Jewish woman of Hamburg, Glikl bas Judah Leib, recent widow of a successful merchant Haim Hamel, also known as Haim Goldschmidt. ${ }^{29}$ Active herself in the jewelry trade at the German fairs and in lending and borrowing on the Hamburg bourse, Glikl continued to raise and marry off the twelve children she and Haim had brought into the world. She also began to write her memoirs, partly moved, she said, by her "aching heart" at his loss, "to help [her] against the melancholy thoughts which came... during many sleepless nights" after 
his death in 1689. Carefully crafted in seven "books", written and in part revised over two decades, the memoirs interspersed Glikl's life history and that of her family with stories: historical and political tales and especially folktales. Her culture was primarily a Yiddish one, with a little German and perhaps a little Hebrew on its margins. But the Yiddish repertory was remarkably well supplied with religious, ethical, historical, and literary works - including collections of folktales.

In the second book of her memoirs, as Glikl had been recounting her parent's lives and her girlhood in Hamburg and adjacent Altona, she introduced a story to show why one should always trust in the Lord. ${ }^{30}$ Once upon a time a pious Talmudist was imprisoned for debt through no fault of his own. While he was in jail, his wife was tricked and kidnapped by a sea captain as she washed clothes near the shore. After his release, the husband took his two sons on board a boat bound for the East Indies, hoping to find his wife, but instead he was shipwrecked and washed up alone in a land of "savages" (vilde leyt).

Here the king's daughter, who had charge of the sheep and cattle, saw him. She was naked and very hairy and wore fig leaves to cover her shame. She approached and made it clear that she loved him and would be his wife. Out of fear, he pretended love, and showed by signs that he would take her.

The other savages saw this... and came leaping from their hill caves. They ran up to him, eager to drink his blood and eat his flesh... The pious Talmudist was so frightened he could hardly breathe. Noting his terror, the king's daughter indicated to him he had no cause to fear, and went to the king and begged him that he let the man live, as she wanted him for her husband. The king agreed and the pious Talmudist was saved.

He lay with her that night, and she was his wife and he was her husband. When he thought of his own beautiful wife and her miserable plight, and that nothing could be altered, he bore his troubles with fortitude, believing that God would help him reach his dear wife and children.

Soon the princess was big with child and in time bore him a savage child, a boy. For two years he lived with them and tended the cattle in the wilderness, eating the flesh of the wild ass and dwelling in a cave in the hillside with his wife. They were now both overgrown with hair and he looked as savage as she.

One day he stood on a small hill not far from the sea, thinking of all that had happened to him: the loss of his wife and children and - heaviest of all - how he had passed all these years living among cruel wild people. Who knew but when with time, they would tire of him and devour his flesh and crush his bones, and he would not be buried among other good Jews, as a pious Jew must be? "Would it not be better for me to run from this hill into the sea and drown myself?" 
At this juncture a heavenly voice dissuaded him from putting an end to himself, led him to a treasure of gold and precious stones, and told him he could escape in an approaching ship bound for Antioch. He shouted to the sailors "that he was a man like them" and they drew up to shore so he could board the boat.

Having heard his shouts, his vilde wife rushed to the shore with their son on her arm and called to him to take her with him. From the boat "he mocked at her and said, 'What have I to do with wild animals? I already have a better wife than you'... When she heard him say that he would return to her no more, anger arose within her. She took the little savage boy by his feet and, tearing him in two, threw one half into the ship and in her rage began to devour the other half. The wise Talmudist sailed away."

Settled on a new island with his treasure and chosen as the native people's duke, the Talmudist was finally reunited with his long-lost wife and sons when their boats happened to dock at his shore and identities were established by the solution of riddles. It turned out that the sea captain also had two wives, a housewife with children back on shore and his kidnapped Jewish one, "very delicate and intelligent," who managed the affairs on board ship for him. But he had never lain with the Talmudist's wife. She had told him that she would sleep only with a man who could equal her former husband by solving a riddle he had taught her. She would kill herself rather than lie with him under any other circumstance, for "it is not right for a peasant lout to ride a king's horse."

Since the sea captain had not touched the Jewish wife, the Talmudist spared his life, merely confiscating his wealth as punishment. Some of the sailors who heard these wonders converted to Judaism, and a Jewish community (kehilah) thereafter flourished on the duke's island.

Glikl's tale is based on the tale-type Placidas or The Man Who Never Swore an Oath, which is found in world traditions from India to medieval Christendom. The Jewish version appeared first in an early medieval Hebrew compilation; in the seventeenth century, a Yiddish telling was published in the celebrated Mayse Bukh. ${ }^{31}$ Here I am, of course, especially interested in the "savage princess episode" in Glikl's recital, what becomes by its ending a "cannibal princess episode." A sea voyage to find the good man's wife is part of the ancient Hebrew version. The Talmudist's liaison with the "savage princess" or anything resembling it is not in the traditional tale at all. Glikl seems to have inserted it herself.

Glikl had turned to travel literature, both Jewish and Christian, for her interlude on the cannibal shore. On the Jewish side, there was the much repeated story of the ninth-century Eldad the Danite, shipwrecked near Ethiopia and cast with another man "among a people called Romranos who are black... tall, without garment... and who eat persons." His companion, plump and healthy, was immediately killed and eaten, but since Eldad was sick, he was kept in chains in hopes he would grow fatter. Instead Eldad hid his food and stayed thin, remaining with the Romranos until seized by some fire-worshipers and finally redeemed by a Jewish merchant from 
Persia. Glikl also had available in Yiddish the medieval tale of the Jerusalemite, who was shipwrecked, saved by and married to a she-demon. When he preferred to return to his first wife and children, she killed him with a kiss. ${ }^{32}$

On the Christian side, there was, of course, the English pilot of Jean Mocquet, just published in German in a town near Hamburg. Possibly, too, some version of the Pocohontas story had got to Hamburg and to Glikl's circle.

Glikl's story combines Jewish sources and European sources, both shaping the outcome of her tale. It also shows her reflecting from a Jewish vantage point on the meanings of cannibalism and on the relation between the imagined "savage" and the imagined "civilized." Glikl was writing her text from Europe at a time when Christian travel literature had been insisting for a century on the similarities between the New World "savage" peoples and the Jews. Certain Amerindian tribes practiced circumcision; other peoples had ceremonies reminiscent of Passover; many communities had menstrual taboos like those of the Jews; and more. Was it not likely, these Christian scholars asked, that the Indians were the descendants of the Lost Tribes of Israel? Even the learned Jewish publicist Menasseh ben Israel gave partial assent to such comparisons. ${ }^{33}$ At its most negative, this comparison involved a similarity between the cannibalism of the Amerindians and the alleged ritual murder by Jews of Christian children. Of the latter charges, Glikl was very much aware and had seen Jews "martyred" on false charges in her own lifetime.

Glikl was also composing her text at a time when Jews had settled in Jamaica, Santo Domingo, and other Caribbean islands and were among the new owners of sugar plantations and of African and Indian slaves in Suriname. These facts were surely known to her, even though she seems to have had no kin or direct business connections in the New World. (Her son-in-law Moses Marcus would sail to India in 1712 and trade in diamonds in Pondicherry and Madras, but that was about twenty years after Glikl had placed the pious Talmudist story in her manuscript.)

Further, Glikl lived in a world where there were numerous pressures on Jews to leave the faith of their fathers and mothers. Hamburg had Lutheran preachers devoted to the task of conversion, and one of Glikl's grandsons was to succumb to their persuasion many years later. How she would have reacted to such betrayal we can guess from her reaction to the news of apostasy that came as she was penning her manuscript. A Jewish trader from Hamburg converted to Christianity to escape hanging for a theft of diamonds from his host in Norway. By his evil action he had "desecrated the name of the Lord." ${ }^{34}$

Within these contexts, boundaries and alterity are central to Glikl's tale, but there are two Others, not one. First, there is the contrast between the learned Jewish husband and his gentle, beautiful and intelligent wife, on the one hand, and on the other, the rather stupid Christian skipper and his wife back home, suitable only for housework. "It is not right for a peasant lout to ride a king's 
horse," the Jewish wife had said to her non-Jewish kidnapper.

Second there is the contrast between the hairy, flesh-eating cave-dwelling shepherds and the learned, skilled Jews. The story of the Pious Talmudist maintains boundaries: intimate connections beyond the Jewish fold will lead to no good. Look what happens to the Talmudist when he lives with the savage princess: he not only becomes hairy, but also violates Scripture and Talmud by eating the non-kosher meat of the wild ass. The danger of the Other is not only external, but lodges within, in one's loins and belly.

In the episode on the "savage" shore, being truly Jewish is equated with being "civilized." The resolution at the end - the Christians converted to Judaism and living under the rule of a wise Talmudist duke and his joyous family - turns the tables on those who see the Jews in league with the devil.

Is this the whole movement in Glikl's tale? Was there any undercurrent of sympathy for the abandoned "savage princess" intended by Glikl in her account? On the surface - and in contrast with Mocquet's reaction to a similar situation - the Talmudist is in the right and is following advice from an angel when he leaves her behind. But only a few pages after the cannibal princess has torn her son in two, Glikl tells a story about a baby being pulled in two directions in her own household. Glikl's own first child had been born at the same time as her mother's last child, and the families were living together with both infants in the room of Glikl's mother and the maid. In the middle of one night, Glikl was sure her mother had the wrong infant in her bed and began to argue with her mother. "No! I have mine in bed with me," said her mother, and held it close to her as though someone was trying to snatch the baby away. Once Glikl had brought a light, the situation was straightened out, and the alarmed household began to laugh. But, concludes Glikl, "we really would have needed King Solomon soon." 35

For Glikl, motherly anguish and possessiveness can be shared across the boundary of "savage" and "civilized," but safe among her own kind, the quarrel could be resolved without a cut.

5. Let me draw together my conclusions as they bear upon the construction of identities in early modern Europe. In the first place, identities are not formed on the basis of a single Other, but of several. People know themselves as belonging to multiple groups: Jean de Léry thinks of himself as a Protestant and a European and a man; Glikl thinks of herself as a Jew and a European and a woman. The Others they construct along the way do not necessarily reinforce each other in a single image. For Léry, a Catholic priest is not just a version of a cannibal. Some traits Léry himself shares with the one, some traits he shares with the other.

In the second place, relations with strange and foreign groups do not entail only the construction of alterity. They can bring forms of knowledge: cognitive as in Rabelais; ethnographic as in Léry; affective, at least to some extent, as in Glikl. This knowledge has uses beyond demarcating the boundaries of the self and legitimizing or delegitimizing domination and possession. Similarities 
between self and others are not only the result of hidden and troubling processes of identification, but are sometimes openly noted and commented on. And some of the noted differences are adiaphoristic: they are of aesthetic and intellectual significance rather than political and moral.

Finally, insofar as subterranean processes of projection are at work in early modern reflection on cannibalism, I would make the following speculation. There are two sides to identification: one with the eaten, the other with the eater. All three texts considered in this essay - that of Rabelais, of Léry, and of Glikl - can be considered in both lights. The horror and fear aroused by such double identification is easier to understand: the horror at killing, the terror at the loss of boundary in such a process of incorporation. Could the hidden desire in such identification be connected with that early modern image of the expectant mother, the woman being eaten by the child, the child in the womb feeding on her? If so, then we have another example, as in witchcraft, of the female body as pregnant in meaning for fundamental processes in early modern Europe. 
${ }^{1}$ Caroline Bynum, The Resurrection of the Body in Western Christianity, 200-1336. New York: Columbia University Press, 1995, pp. 33-42, 55, 103-104, 111-112. Maggie Kilgour, From Communion to Cannibalism. An Anatomy of Metaphors of Incorporation. Princeton: Princeton University Press, 1990, pp. 46-62, especially p. 51.

2 Bynum, Resurrection, pp. 219, 263. William lan Miller, The Anatomy of Disgust. Cambridge, Mass.: Harvard University Press, 1997, p. 156. R. Po-Chia Hsia, The Myth of Ritual Murder. Jews and Magic in Reformation Germany. New Haven and London: Yale University Press, 1988, pp. 5-9. Ritual cannibalism in Europe has also been given intensive treatment by Edward Muir, Ritual in Early Modern Europe. CUP 1997, chapters 3 and 6.

${ }^{3}$ Georges Duby, ed., L' An Mil. Paris: Gallimard, 1967, pp. 112-116, quoting Rudolphus Glaber on the femine of Burgundy in 1033.

${ }^{4}$ Frank Lestringant, Le Cannibale. Grandeur et décadence. Paris: Perrin, 1994.

${ }^{5}$ Claudine Fabre-Vassas, La bête singulière: Les Juifs,les Chrétiens, et le cochon. Paris: Gallimard, 1994, chap. 4. Keith Thomas, Man and the Natural World. Changing Attitudes in England, 1500-1800. New York and Oxford: Oxford University Press, 1983, pp. 17-18, 288-295.

${ }^{6}$ Hierosme de Monteux, Commentaire de la conservation de santé et prolongation de vie. Lyon: Jean de Tournes, 1559, pp. 37, 46. François Chappuys, Sommaire contenant certains et vrays remedes contre la Peste. Lyon: Jean and François Frellon, 1544, chap. 6.

${ }^{7}$ «Explications morales d'aucuns proverbes communs en la langue francoyse," in Thresor de la langue francoyse tant ancienne que moderne. Paris: David Douceur, 1606, p. 18.

${ }^{8}$ Anthony Pagden, The Fall of Natural Man. The American Indian and the Origins of Comparative Ethnology. Cambridge: Cambridge University Press, 1982, pp. 80-90. Francisco de Vitoria's De Indis was composed in 1539 and circulated widely in manuscript until its first appearance in print in 1557.

${ }^{9}$ Inga Clendinnen, Aztecs. An Interpretation. Cambridge: Cambridge University Press, 1991, chap. 10. Pagden, Fall of Natural Man, pp. 97-100.

${ }^{10}$ François Rabelais, Pantagruel, chap. 9 in Mireille Huchon (ed.), Oeuvres complètes. Paris: Gallimard, 1994, pp. 246-250.

${ }^{11}$ Rabelais, Pantagruel, chap. 14 in Mireille Huchon (ed.), Oeuvres, pp. 262-267.

${ }^{12}$ See the excellent discussion of these issues in Timothy Hampton, "'Turkish Doges'; Rabelais, Erasmus, and the Rhetoric of Alterity", Representations, 41 (Winter 1993), pp. 58-82.

${ }^{13}$ Jean de Léry, Histoire d'un voyage fait en la terre du Bresil autrement dite Amerique (n.p. [Geneva]: Antoine Chuppin, 1578); second ed. Geneva: Antoine Chuppin, 1580. Léry told the story of his writing and rewriting of the manuscript in his Preface. My citations here are from the excellent English translation of the 1580 edition by Janet Whatley: Jean de Léry, History of a Voyage to the Land of Brazil. Berkeley and Los Angeles: University of California Press, 1990. Whatley's Introduction is also very useful.

${ }^{14}$ Léry, Voyage, Preface, especially pp. Ix-Ixii.

${ }^{15}$ ibid., pp. 67, 69, 144.

${ }^{16}$ Much of Léry's description of the treatment of prisoners and the consumption of human flesh is contained 
in chapter 15, «How the Americans treat their prisoners of war and the ceremonies they oberve both in killing and in eating them.».

${ }^{17}$ ibid., pp. 126-127.

${ }^{18}$ ibid., p. 127. Léry says nothing about the Tupinambas hoping to acquire the qualities of the enemies whose flesh they eat. In discussing their attitudes toward the consumption of animals and birds, however, he reports that they will not eat certain ducks, any beast, and even some fish that move slowly, for they fear that if they do, they will run slowly and be unable to escape from their enemies (pp. 86-87).

${ }^{19}$ ibid., pp. 126, 128, 131, 190.

${ }^{20}$ ibid., pp. 121, 125.

${ }^{21}$ ibid., pp. 93-94, 128, 132. Inspired by Léry's text, Michel de Montaigne made a similar contrast in his «Des cannibales» between the behavior of the Brazilians and the behavior of the French in the religious wars (Essais, 1:31).

22 ibid., pp. 208-214.

${ }^{23}$ ibid., p. 212. Jean de Léry, Histoire mémorable de la Ville de Sancerre, contenant les entreprinses, siege... les resistances... la famine extreme [et] delivrance. n.p. [Geneva], 1574.

${ }^{24}$ ibid., pp. 41, 132.

${ }^{25}$ Pierre Viret, De la communication des fideles, qui cognoissent la verité de l'evangile, aux ceremonies des papistes. n.p. [Geneva?], n.p., 1560, pp. 91-93. Antonio Mainardo, Anatomie de la messe et de messel. n.p. [Lyon], 1562, pp. 18-19, 233-234.

${ }^{26}$ Jean Mocquet, Voyages en Afrique, Asie, Indes Orientales et Occidentales. Faits par lean Mocquet, Garde du Cabinet des singularitez du Roy, aux Tuilleries. Rouen: Jacques Caillové, 1645; first edition was 1616, Book 2, especially pp. 148-150.

${ }^{27}$ Peter Hulme, Colonial Encounters. Europe and the Native Caribbean 1492-1797. London and New York: Routledge, 1986, chap. 6.

${ }^{28}$ Jean Mocquet, Wunderbare jedoch gründlich-und warhaffte geschichte und reise begebnisse in Africa, Asia, Ost-un West-Indien, trans. Johan Georg Schochen. Lüneberg: J. G. Lippers, 1688, pp. 84-85.

${ }^{29}$ I have treated the life and autobiography of Glikl bas Judah Leib more fully in Women on the Margins. Three Seventeenth-Century Lives. Cambridge, Mass.: Harvard University Press, 1995, chap. 1.

${ }^{30}$ David Kaufmann (ed.), Die Memoiren der Glückel von Hameln, 1645-1719, Yiddish, Frankfurt am Main: J. Kaufmann, 1896, pp. 39-57. The Life of Glückel of Hameln, 1646-1742, Written by Herself, trans. BethZion Abraham. London: Horovitz, 1962, pp. 22-31.

31 "The Man Who Would Not Take an Oath," in A. Aarne and Stith Thompson, The Types of the Folk-Tale: A Classification and Bibliography. 2nd ed. Helsinki: Suomalainen Tiedeakatemia, 1964, no. 938: Placidas, pp. 331-332. "The Reward of Virtue, or the Story of the Man Who Never Took an Oath", in Ma'aseh Book. Book of Jewish Tales and Legends, trans. Moses Gaster. Philadelphia: Jewish Publication Society, 1981, no. 222, pp. 542-546. E. Yassif, "From Jewish Oicotype to Israeli Oicotype: The Tale of 'The Man Who Never Swore an Oath'”, Fabula, 27 (1986), pp. 216-236. 
${ }^{32}$ Elkan Nathan Adler, (ed.), Jewish Travellers: A Treasury of Travelogues from Nine Centuries. 2nd ed. New York, 1966, pp. 4-7. Dan Ben-Amos, (ed.), Mimekor Yisrael: Clasical Jewish Folktales, collected by Micha Joseph bin Gorion, trans. I. M. Lask, abridged by Dan Ben-Amos. Bloomington: Indiana University Press, 1990, nos. 200-201, pp. 373-386.

${ }^{33}$ Howard Eilberg-Schwartz, The Savage in Judaism: An Anthropology of Israelite Religion and Ancient Judaism. Bloomington: Indiana University Press, 1990, pp. 31-41; Richard Popkin, "The Rise and Fall of the Jewish Indian Theory", in Yosef Kaplan, Henry Méchoulan, and Richard H. Popkin (eds.), Menassah ben Israel and His World. Leiden: E. Brill, 1989, pp. 63-82.

${ }^{34}$ Memoiren, pp. 134-142; Life, pp. 75-76.

${ }^{35}$ Memoiren, pp. 72-73; Life, pp. 39-40. 